\title{
Rotavirus morbidity and mortality in children in Brazil
}

\author{
Ana Marli Christovam Sartori, ${ }^{1}$ Joice Valentim, ${ }^{2}$ Patrícia Coelho de Soárez, ${ }^{2}$ \\ and Hillegonda Maria Dutilh Novaes ${ }^{2}$
}

Suggested citation Sartori AMC, Valentim J, de Soárez PC, Novaes HMD. Rotavirus morbidity and mortality in children in Brazil. Rev Panam Salud Pública. 2008;23(2):92-100.

ABSTRACT Objective. To study the epidemiology of rotavirus and estimate rotavirus-associated morbidity and mortality in children $\leq 5$ years of age in Brazil in 2004 before introducing the rotavirus vaccine in Brazil's National Immunization Program (Programa Nacional de Imunizações, PNI).

Methods. To estimate rotavirus morbidity, published studies (1999-2006) addressing incidence of acute diarrhea among children $\leq 5$ years of age and frequency of rotavirus infection among children with diarrhea in Brazil were reviewed. Diarrhea episodes were divided into three categories of severity by level of care: mild cases requiring only home-based care; moderate cases requiring a visit to an outpatient healthcare facility; and severe cases requiring hospitalization. To estimate rotavirus mortality, information on the number of registered deaths from diarrhea in children $\leq 5$ years of age was obtained from the Mortality Information System (Sistema de Informação sobre Mortalidade, SIM) of Brazil's public healthcare system (Sistema Único de Saúde, SUS) and the proportion of deaths due to rotavirus was calculated.

Results. Rotavirus infections were estimated to cause 3525053 episodes of diarrhea, 655853 visits to outpatient healthcare facilities, 92453 hospitalizations, and 850 deaths of children $\leq 5$ years of age each year in Brazil.

Conclusion. Rotavirus infections are an important cause of child morbidity and mortality in Brazil.

Key words Rotavirus, mortality, morbidity, Brazil.

1 Clínica de Moléstias Infecciosas e Parasitárias, Hospital das Clínicas da Faculdade de Medicina da Universidade de São Paulo, Sao Paulo, Brasil. Send correspondence and requests for reprints to: Ana Marli C. Sartori, Clínica de Moléstias Infecciosas e Parasitárias, Hospital das Clínicas da Faculdade de Medicina da Universidade de São Paulo, Av. Dr. Enéas de Carvalho Aguiar, 455, 4o andar, sala 4028 Cerqueira Cesar, Sao Paulo 05403000, Brasil; telephone: +55 (11) 3069 7517; fax: +55 (11) 3069 7508; e-mail: anasartori@gmail.com

2 Departamento de Medicina Preventiva, Faculdade de Medicina da Universidade de São Paulo, Sao Paulo, Brasil.
Diarrhea-associated morbidity and mortality remains a significant problem among children in developing countries. For the past several decades, efforts have been made worldwide to combat this ubiquitous health problem. In Brazil, as in many other countries, morbidity and mortality due to diarrheal disease decreased sharply in the 1970s (1-3). Improve- ments in potable water supply and household sanitation are considered to have had a very important role (2-3). By the 1980s, the decrease in severe diarrhea and mortality was also influenced by the increasing use of oral rehydration therapy (ORT), the promotion of breast-feeding, and improvement in children's nutritional status (2-4). Despite these achieve- 
ments, regional and socioeconomic differences in diarrhea morbidity and mortality persisted into the 1990s, even though access to healthcare services improved countrywide and the use of ORT did not vary significantly across different regions (3-4). In Southeast Brazil, which has better average socioeconomic conditions than other parts of the country, the sharp reduction in mortality due to diarrhea was accompanied by changes in seasonal patterns (5-6). Analysis of the temporal patterns of hospitalization and deaths from diarrhea among children $\leq 5$ years of age in the Southeastern state of Rio de Janeiro from 1995 to 1998 revealed winter rather than summer peaks, suggesting viruses are the predominant etiologic agents of severe diarrhea (5-6). Diarrhea caused by bacteria and parasites, which are transmitted mainly through contaminated food or water, is more prevalent during the summer, as opposed to diarrhea caused by rotavirus infection, which is spread from person-to-person and is more frequent in the cold and dry season (7).

Rotavirus is the most common cause of severe diarrhea among children, with an estimated 111 million diarrhea episodes, 25 million outpatient healthcare facility visits, 2 million hospitalizations, and 440000 deaths among children $\leq 5$ years worldwide attributable to the disease each year (8). By 5 years of age, nearly all children will have had an episode of rotavirus gastroenteritis. While the incidence of rotavirus infections does not differ significantly between developing and industrialized countries, most deaths occur in underdeveloped countries, where infection seems to occur earlier in life and a broad diversity of rotavirus strains are observed (8).

The similar incidence of rotavirus infections in both industrialized and developing countries suggests that it can not be controlled through improved water supply and sanitation alone (7). Therefore, to prevent severe rotavirusassociated disease and deaths, the universal use of rotavirus vaccine has been recommended (9). Two new live oral vaccines have recently been made available commercially-a monovalent attenuated G1P[8] human rotavirus vaccine (10) and a pentavalent humanbovine reassortant rotavirus vaccine containing human serotypes G1, G2, G3, G4, and P[8] (11). Both products have demonstrated efficacy against severe rotavirus-associated disease and a reassuring safety profile in phase 3 trials (10-11). The accelerated introduction of rotavirus vaccine in national immunization programs, particularly in developing countries, is considered a priority by the World Health Organization (WHO) (9).

The sentinel surveillance system for diarrheal disease, proposed by the Brazilian Ministry of Health $(\mathrm{MOH})$ in 1994 and currently active in around $80 \%$ of municipalities, has identified an increasing number of outbreaks and provided a great deal of information about rotavirus infection in different regions of Brazil. Knowledge of the epidemiology of rotaviruses in the country as a whole remains limited, however, due to the lack of population-based national studies (12-13).

The main objectives of this study were to understand the epidemiology of rotavirus infection in Brazil in the pre-vaccine era and to estimate rotavirus-associated disease and death in children $\leq 5$ years of age in order to provide data for a baseline epidemiological diagnosis that may be useful for cost-effectiveness studies as well as rotavirus vaccine impact monitoring.

\section{MATERIALS AND METHODS}

\section{Selection of studies}

To identify studies of diarrhea episodes among children $\leq 5$ years of age in Brazil, a computer search of scientific literature was conducted in PubMed and LILACS (Latin American and Caribbean Literature on Health Sciences) databases using the keywords "diarrhea" and "Brazil" simultaneously. Cross-sectional surveys and longitudinal community-based cohort studies published in Portuguese and English between 1999 and March 2006 were selected.
For studies that included results on diarrhea prevalence but not estimated annual incidence, the 2-week prevalence rate was converted to a 2-week incidence rate as described below (14):

$\begin{array}{lll}\begin{array}{l}2 \text {-week } \\ \text { diarrhea } \\ \text { prevalence } \\ \text { rate }\end{array} & \begin{array}{l}14 \text { [days] } \\ 14+\text { average } \\ \text { duration } \\ \text { (number of } \\ \text { days) of a } \\ \text { diarrhea episode }\end{array}\end{array}$

The average duration of a diarrhea episode was estimated as 3 days.

The 2-week diarrhea incidence rate was then multiplied by 26 (the number of 2-week periods in a year) (14) to estimate annual incidence of diarrhea (per child). Correction for seasonality was not applied.

National administrative data were also collected on hospitalization of children $\leq 5$ years of age for diarrhea ${ }^{3}$ by the public healthcare system (Sistema Único de Saúde, SUS) in 2004, based on registration records from the SUS Hospital Information System (Sistema de Informações Hospitalares, SIH) (15), and number of deaths of children $\leq 5$ years of age from diarrhea in 2003 (the last year for which definitive data were available), based on registration records from the national public health database (Departamento de Informática do Sistema Único de Saúde, DATASUS) Mortality Information System (Sistema de Informação sobre Mortalidade, SIM) (16). These data are freely available and in the public domain (15-16).

To identify studies of frequency of rotavirus disease among children $\leq 5$ years of age with diarrhea in Brazil, a computer search of scientific literature was conducted in PubMed and LILACS using the keywords "rotavirus" and "Brazil" simultaneously. Community-based and healthcare services studies published in Portuguese and English between 1999 and March 2006 were selected. The review included studies that lasted at least 12

\footnotetext{
3 As per WHO International Statistical Classification of Diseases and Related Health Problems 10th Revision (ICD-10) disease codes A00 to A09.
} 
consecutive months and observed at least 100 children. All methods of rotavirus detection (enzyme-linked immunosorbent assay [ELISA]; polyacrylamide gel electrophoresis [PAGE]; latex tests; and passive hemagglutination) were considered. Letters and editorials as well as studies limited to circulating rotavirus strains (i.e., the distribution and prevalence of $G$ and $P$ serotypes [17]) were excluded. The studies were grouped and analyzed by healthcare setting-hospital, outpatient or mixed (outpatient + hospital) facility, and home-based.

\section{Estimates of rotavirus-associated disease and deaths}

To estimate the impact of rotavirusassociated diarrhea among children $\leq 5$ years of age in Brazil, a model used by Parashar et al. (8) was adopted. The population of Brazilian children $\leq 5$ years of age in 2004 (18) was multiplied by the estimated annual incidence of diarrhea. These episodes of diarrhea were then sorted into three categories of severity by level of care: mild cases requiring only home-based care, moderate cases requiring care in outpatient healthcare facilities, and severe cases requiring hospitalization. Next, the total number of episodes in each category was multiplied by the estimated proportion attributable to rotavirus to yield the number of rotavirus cases in each category.

To estimate annual incidence of rotavirus-associated diarrhea per child, the number of reported episodes of mild, moderate, and severe diarrhea was divided by the estimated number of children under 5 in the 2004 cohort (18). These annual incidence figures were then multiplied by 5 in order to estimate the 5-year cumulative incidence of rotavirus-associated diarrhea per child.

To estimate the number of deaths from rotavirus-associated diarrhea in Brazil, the number of deaths of children $\leq 5$ years of age from diarrhea in 2003 (16) was multiplied by the proportion of rotavirus among children with severe diarrhea.
The risk of dying from rotavirus by age 5 was then calculated by dividing the number of births in Brazil in 2004 (3 210 361) (Instituto Brasileiro de Geografia e Estatística, IBGE) by the number of estimated rotavirus-associated deaths in the cohort of children under 5 in 1 year (assuming the number of events in a birth cohort followed for 5 years is similar to the number of events in a cohort of children under 5 followed for 1 year).

\section{RESULTS}

\section{Incidence of diarrhea episodes among children $\leq 5$ years of age}

Five surveys and five prospective longitudinal studies of diarrhea episodes in children $\leq 5$ years of age in Brazil were identified (Table 1) (4; 19-27). Most involved local or regional communities, and one longitudinal study lasted less than 12 consecutive months (23). There were significant regional differences in the incidence of diarrhea in children $\leq 5$ years of age in Brazil (Table 1), ranging from 1.04 episodes per child per year in the city of São Paulo in Southeast Brazil (26) to 5.55 among children living in households without proper sanitation in Salvador (Bahia state) in Northeast Brazil (21). The results of a national cross-sectional survey conducted in 1996 that estimated the incidence of diarrhea in children $\leq 5$ years of age at 3.1 episodes per child per year countrywide (4.06 for the Northeast region and 2.48 for the rest of the country) (4) was adopted to calculate the number of diarrhea episodes. The proportions of mild, moderate, and severe episodes were calculated based on a community-based study conducted in Salvador in which the proportion of children with diarrhea who required an outpatient healthcare facility visit was $11.6 \%$ and the proportion of children who required hospitalization was $0.7 \%$ (22). In a community-based study conducted in São Paulo, the proportion of children with diarrhea who required hospitalization was $0.76 \%$ (26).
Multiplying the estimated population of children $\leq 5$ years of age in Brazil in 2004 (14 590732 [18]) by estimated incidence of diarrhea (3.1) resulted in 45231269 episodes of diarrhea distributed across the three categories of severity by level of care: hospitalizations $(0.7 \%$, or 316619 episodes); care at outpatient healthcare facilities $(11.6 \%$, or 5246827 episodes); and home-based care $(87.7 \%$, or 39667823 episodes).

The estimate of 316619 hospitalizations compared well with the national administrative data: In 2004, 259669 children $\leq 5$ years of age were hospitalized in the public healthcare system due to diarrhea, based on SIH/SUS registration records (15). Children in their first year of life accounted for 98703 (37.8\%) of these hospitalizations. Because $\mathrm{SIH}$ registries only include events occurring in the public healthcare system, this number (259 669) was adjusted to include the private sector. Data from a national household survey (Pesquisa Nacional por Amostra de Domicílios, PNAD) conducted in 2003 indicated the public healthcare system was responsible for $77 \%$ of all hospitalizations of children under 5 in Brazil, whereas the private sector was responsible for $23 \%$ (28). Taking into account the participation of the private sector, based on administrative data, an estimated total of 337232 children $\leq 5$ years of age were hospitalized for diarrhea in Brazil in 2004.

\section{Frequency of rotavirus detection among children with diarrhea}

Fifteen studies that met the criteria for inclusion were identified, eight of them involving hospitalized children and nine involving children treated at outpatient healthcare facilities or mixed (outpatient + hospital) facilities. The frequency of rotavirus detection among children $\leq 5$ years of age hospitalized for diarrhea in Brazil ranged from $15 \%$ to $36.7 \%$, with a median of $29.2 \%$ (Table 2) (29-36). Among children $\leq 5$ years of age with diarrhea seen at outpatient healthcare facilities, the frequency of rotavirus detection 
TABLE 1. Community-based studies on morbidity rates caused by diarrhea in children in Brazil (1999-2006)

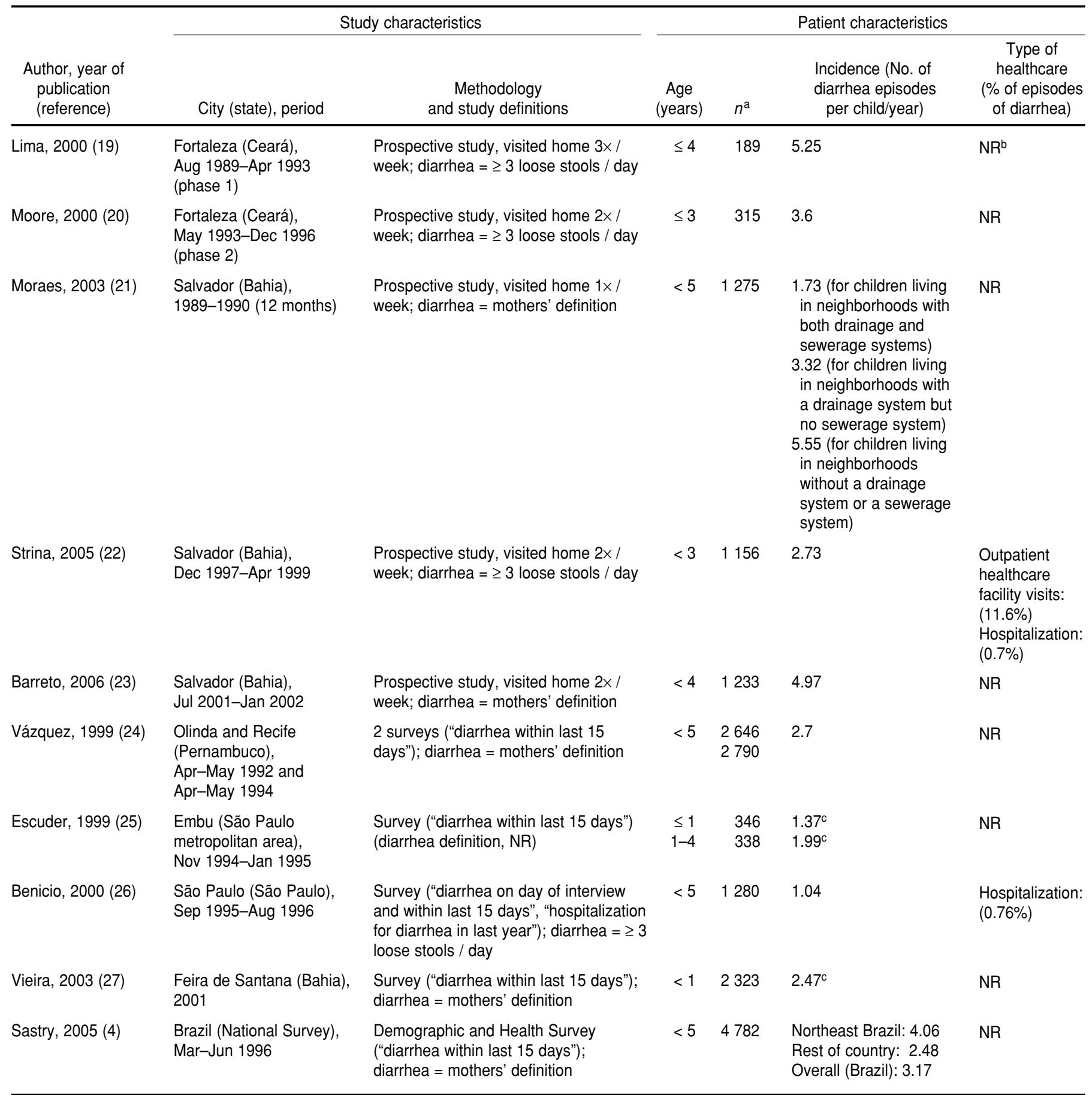

a Number of patients.

${ }^{b}$ Not reported.

${ }^{c}$ Authors' estimates based on 2-week prevalence reported in original study (without correction for seasonality) (14).

ranged from $3.8 \%$ to $23 \%$, with a median of $12.5 \%$ (Table 3) (32-33; 36-41). Only two community-based studies reported the frequency of rotavirus de- tection. In one of them, involving children $<3$ years of age with diarrhea in Fortaleza (Ceará state), rotavirus was detected in 6\% (12 out of 199 cases)
(19). In the other, which included children $<4$ years of age with diarrhea in Salvador, rotavirus infections were found in $7.9 \%$ (11 out of 139 cases) (23). 
TABLE 2. Frequency of rotavirus detection in children hospitalized for acute diarrhea in Brazil (1999-2006)

\begin{tabular}{|c|c|c|c|c|c|c|}
\hline \multirow[b]{2}{*}{$\begin{array}{l}\text { Author, year } \\
\text { of publication } \\
\text { (reference) }\end{array}$} & \multicolumn{3}{|c|}{ Study characteristics } & \multicolumn{3}{|c|}{ Patient characteristics } \\
\hline & City (state) & Period & Detection assay & $\begin{array}{c}\text { Age } \\
\text { (years) }\end{array}$ & $n^{\mathrm{a}}$ & $\begin{array}{c}\% \text { infected } \\
\text { with } \\
\text { rotavirus }\end{array}$ \\
\hline Araújo, 2002 (29) & Rio de Janeiro (Rio de Janeiro) & May 1996-Dec 1998 & $\mathrm{ELISA}^{\mathrm{b}} / \mathrm{PAGE}^{\mathrm{c}}$ & $<3$ & 619 & 15.0 \\
\hline Domingues, 2000 (30) & Rio de Janeiro (Rio de Janeiro) & Jan 1995-Jun 1996 & ELISA / PAGE & $<5$ & 102 & 15.7 \\
\hline Gusmão, 1999 (31) & Belém (Pará) & Nov 1992-Nov 1994 & ELISA / PAGE & $<5$ & 181 & 20.9 \\
\hline Rosa e Silva, 2002 (33) & Juiz de Fora (Minas Gerais) & Jan 1998-Dec 1999 & PAGE & $<5$ & 212 & 29.2 \\
\hline Santos, 2005 (34) & Salvador (Bahia) & $1999-2000$ and 2002 & PAGE & $<5$ & 648 & 32.0 \\
\hline Luz, 2005 (35) & São Luiz (Maranhão) & Jun 1997-Jun 1999 & ELISA / PAGE & $<3$ & 128 & 32.0 \\
\hline Carmona, 2004 (36) & São Paulo (São Paulo) & Aug 1994-Jul 1995 & ELISA & $<5$ & 49 & 36.7 \\
\hline
\end{tabular}

a Number of patients.

b Enzyme-linked immunosorbent assay.

c Polyacrylamide gel electrophoresis.

TABLE 3. Frequency of rotavirus detection in children seen at healthcare facility (hospital, outpatient, or mixed [outpatient + hospital]) for acute diarrhea in Brazil (1999-2006)

\begin{tabular}{|c|c|c|c|c|c|c|}
\hline $\begin{array}{l}\text { Author, year } \\
\text { of publication } \\
\text { (reference) }\end{array}$ & \multicolumn{3}{|c|}{ Study characteristics } & \multicolumn{3}{|c|}{ Patient characteristics } \\
\hline Rosa e Silva, $2002(33)^{b}$ & Juiz de Fora (Minas Gerais) & Jan 1998-Dec 1999 & $\mathrm{PAGE}^{\mathrm{C}}$ & $<5$ & 844 & 3.8 \\
\hline Volotão, $2006(37)^{d}$ & Rio de Janeiro (Rio de Janeiro) & Jan 2000-Jul 2004 & PAGE & $<5$ & 1568 & 8.2 \\
\hline \multirow[t]{2}{*}{ Soares, $2002(39)^{d}$} & $\begin{array}{l}\text { Rio de Janeiro (Rio de Janeiro) } \\
\text { Niterói (Rio de Janeiro) } \\
\text { Londrina (Paraná) } \\
\text { Juiz de Fora (Minas Gerais) }\end{array}$ & $\begin{array}{l}\text { Feb 1998-Jul } 2000 \\
2000 \\
2000 \\
\text { Feb 1998-Jul } 1999\end{array}$ & PAGE & $<5$ & $\begin{array}{r}666 \\
77 \\
110 \\
760\end{array}$ & $\begin{array}{r}15.8 \\
3.9 \\
6.4 \\
10.3\end{array}$ \\
\hline & Total & & & & 1613 & 12.0 \\
\hline Carmona, $2004(36)^{b}$ & São Paulo (São Paulo) & Aug 1994-Jul 1995 & ELISA & $<5$ & 68 & 22.0 \\
\hline Santos, $2001(41)^{d}$ & $\begin{array}{l}\text { Rio de Janeiro and Niterói } \\
\text { (Rio de Janeiro) }\end{array}$ & Mar 1997-Dec 1999 & PAGE / latex & $<5$ & 678 & 23.0 \\
\hline
\end{tabular}

a Number of patients.

b Studies involving only children treated at outpatient healthcare facilities.

c Polyacrylamide gel electrophoresis.

d Studies involving population treated at mixed (outpatient + hospital) healthcare facility.

e Enzyme-linked immunosorbent assay.

\section{Estimates of rotavirus-associated diarrhea episodes}

The estimated number of diarrhea episodes attributable to rotavirus in each of the three categories of severity by level of care (hospital, outpatient healthcare facilities, and home-based) and the estimated total number of rotavirus-associated diarrhea episodes in children $\leq 5$ years of age in Brazil are shown in Table 4 . In the base-case analysis, the incidence of rotavirusassociated diarrhea was estimated using the median rates of rotavirus detection in each category. The incidence of rotavirus-associated diarrhea in "best-case" and "worst-case" scenarios 
TABLE 4. Estimated numbers of diarrhea episodes from all causes and diarrhea episodes and deaths attributable to rotavirus among children $\leq 5$ years in Brazil in 2004

\begin{tabular}{|c|c|c|c|}
\hline \multicolumn{3}{|c|}{ Estimated population of children $<5$ years of age } & 14590732 \\
\hline \multicolumn{3}{|c|}{ Estimated incidence of diarrheal disease (all causes) } & $3.1 /$ child \\
\hline \multicolumn{3}{|c|}{ Number of episodes of acute diarrhea } & 45231269 \\
\hline \multicolumn{4}{|c|}{$\begin{array}{l}\text { Mild cases (requiring home-based care) } \\
\text { Moderate cases (requiring outpatient healthcare }\end{array}$} \\
\hline \multicolumn{4}{|c|}{$\begin{array}{l}\text { Moderate cases (requiring outpatient healthcare } \\
\text { facilities visit) }\end{array}$} \\
\hline \multicolumn{4}{|c|}{ Diarrhea attributable to rotavirus } \\
\hline Episodes & Base-case scenario & Low-case scenario & High-case scenario \\
\hline Mild & $(7.0 \%) \quad 2776747$ & $(6.0 \%) \quad 2380069$ & $(7.9 \%) 3133758$ \\
\hline Moderate & $(12.5 \%) \quad 655853$ & 199379 & $(23 \%) 1206770$ \\
\hline Severe & $(29.2 \%)$ & 47493 & $(36.7 \%) \quad 116199$ \\
\hline Total & 3525053 & 2626941 & 4456727 \\
\hline Rotavirus-associated deaths & 850 & 437 & 1069 \\
\hline
\end{tabular}

TABLE 5. Five-year cumulative incidence of rotavirus-associated diarrhea episodes and risk of dying from rotavirus-associated diarrhea by age 5 (2004 birth cohort)

\begin{tabular}{lccc}
\hline Rotavirus-associated diarrhea (per child) & $\begin{array}{c}\text { Base-case } \\
\text { scenario }\end{array}$ & $\begin{array}{c}\text { Low-case } \\
\text { scenario }\end{array}$ & $\begin{array}{c}\text { High-case } \\
\text { scenario }\end{array}$ \\
\hline $\begin{array}{l}\text { Mild (requiring home-based care) } \\
\text { Moderate (requiring outpatient }\end{array} \quad 0.9515$ & 0.8156 & 1.074 \\
$\quad$ healthcare facilities visit) & 0.2247 & 0.068 & 0.4135 \\
Severe (requiring hospitalization) & 0.0316 & 0.0163 & 0.0398 \\
Total & 1.208 & 0.9 & 1.5272 \\
Risk of dying from rotavirus by age 5 & 1 in 3 777 & 1 in 7 346 & 1 in 3 003 \\
\hline
\end{tabular}

was also calculated, using the frequency of rotavirus infection according to the lowest and highest rates of rotavirus detection in the reviewed studies (Table 4). In the base-case analysis, among children $<5$ years of age, an estimated 3525053 diarrhea episodes, 655853 visits to outpatient healthcare facilities, and 92453 hospitalizations related to rotavirus occurred each year in Brazil.

The estimated incidence of rotavirusassociated diarrhea among children $<5$ years of age is 0.242 episodes per child per year (base-case analysis), with a low-case to high-case range from 0.18 to 0.306 . The 5-year cumulative incidence of rotavirus-associated diarrhea is presented in Table 5.

\section{Estimates of deaths from rotavirus- associated diarrhea}

There were 2913 deaths from diarrhea $-4.3 \%$ of all deaths $(67846)$ of children $\leq 5$ years of age in Brazil in 2003 (16). Children in their first year of life accounted for most of these deaths (2 387 or $81.9 \%$ ).

Multiplying the number of diarrhea deaths by the proportion of rotavirus detection in children hospitalized for diarrhea (median, 29.2\%; minimum, $15 \%$; and maximum, $36.7 \%$ ) resulted in an estimated 850 (minimum, 437; maximum, 1 069) deaths of children $\leq 5$ years of age from rotavirus-associated diarrhea in Brazil in 2003.

The risk of dying from rotavirusassociated diarrhea by age 5 is presented in Table 5.

\section{DISCUSSION}

Estimates of the impact of rotavirusassociated diarrhea in childhood in Brazil in the pre-vaccine era were calculated using national data from published research and from the SIH/SIM
(SUS Hospital and Mortality Information Systems). These estimates indicated rotavirus infections are an important factor in morbidity and mortality among Brazilian children $\leq 5$ years of age, causing 3525053 episodes of diarrhea, 655853 visits to outpatient healthcare facilities, 92453 hospitalizations, and 850 deaths per year, using base-case estimates, or 1.2 episodes of rotavirus-associated diarrhea per child in the first 5 years of life.

It should be noted that these estimates reflect the situation a decade ago, when most of the studies included in this review were conducted. To incorporate parameter uncertainties in the study estimates, additional "best-case" and "worst-case" scenarios were calculated.

Another limitation of this study is the fact that most of the literature reviewed involved selected populations that may not be representative of the entire country. The estimated proportions of diarrhea episodes distributed across the three categories of severity by level of care-home-based care $(87.7 \%)$, a visit to an outpatient healthcare facility $(11.6 \%)$, or hospitalization $(0.7 \%)$ - were based on only two local studies. While there are still significant regional differences in diarrhea morbidity in Brazil, healthcare access, particularly for primary care and hospital care for acute conditions for children $\leq 5$ years old, is not significantly different and is of an acceptable quality in urban areas countrywide (3). One interesting finding is that the proportions of diarrhea episodes by level of care observed in Brazilian studies were similar to those found in a Chilean study involving $\leq 11$-monthold infants and 1- to 4-year-old children. These study results, respectively, were as follows: $88.2 \%$ and $91.9 \%$ of diarrhea episodes required only home-based care, $10.3 \%$ and $7.9 \%$ required an outpatient healthcare facility visit, and $1.5 \%$ and $0.2 \%$ required hospitalization (8). There are no official data on the number of visits to outpatient healthcare facilities due to diarrhea in Brazil, but the number of hospital registrations for diarrhea, as per the SUS Hospital Information Sys- 
TABLE 6. Proportion of rotavirus detection among children < 5 years of age with diarrhea in different settings (hospital, outpatient or mixed [outpatient + hospital], and community-based study) in Latin America (1998-2007)

\begin{tabular}{|c|c|c|c|c|c|c|}
\hline \multirow{3}{*}{$\frac{\text { Location (reference) }}{\text { Brazil (this study) }}$} & \multicolumn{6}{|c|}{$\begin{array}{l}\text { Proportion of rotavirus detection } \\
\text { (median \% / range) }\end{array}$} \\
\hline & \multicolumn{2}{|c|}{$\begin{array}{l}\text { Hospital } \\
(\%)\end{array}$} & \multicolumn{2}{|c|}{$\begin{array}{c}\text { Outpatient or mixed } \\
\text { (outpatient }+ \text { hospital) facility } \\
(\%)\end{array}$} & \multicolumn{2}{|c|}{$\begin{array}{c}\text { Community-based } \\
\text { study } \\
(\%)\end{array}$} \\
\hline & 29.2 & $(15-36.7)$ & 12.5 & (3.8-23) & 7 & $(6-7.9)$ \\
\hline Latin America (42) & 31 & $(16-52)$ & 30.5 & $(4-42)$ & $\mathrm{NR}^{\mathrm{a}}$ & \\
\hline Argentina (43) & 20 & $(6-54)$ & 9 & $(5-22)$ & 10 & \\
\hline Argentina (44) & 71 & & 39 & & NR & \\
\hline Chile (44) & 47 & & 34 & & NR & \\
\hline Venezuela (44) & 38 & & 29 & & NR & \\
\hline Venezuela (45) & 33 & & 23 & & NR & \\
\hline El Salvador (46) & 35 & & 27 & & NR & \\
\hline Peru (47) & 32 & $(12-52)$ & 19 & & 3.4 & $(2.6-4.2)$ \\
\hline Peru (48) & 41 & & NR & & NR & \\
\hline
\end{tabular}

a Not reported.

tem, provided an essential reference point that strengthened this study's estimates, with the two independent approaches used to calculate hospitalizations for diarrhea providing nearly identical numbers.

Although rotavirus is most frequently detected in Brazilian children with severe diarrhea, great variations were observed in the proportions of rotavirus detection across different studies-from $15 \%$ to $36.7 \%$ (median $29.2 \%$ ) in hospitalized children, and from $3.8 \%$ to $23 \%$ (median $12.5 \%$ ) in children cared for in outpatient healthcare facilities. A high degree of variation in rotavirus detection has also been observed in other studies conducted in South America (42-48) (Table 6). This variation could be due to the difference in age groups across the study populations, which included children under 2 years in Peru (48); children under 3 in Argentina, Chile, and Venezuela (44); and children under 5 in Venezuela (45) and El Salvador (46). It may also reflect differences in the sensitivity of the assays used across studies and/or geographic and temporal differences in the prevalence of the various etiologic agentsi.e., competing pathogens-of diarrheal disease. In a review of severe diarrhea in childhood, Parashar et al.
(7) observed a $17 \%$ increase in the rate of rotavirus among children hospitalized for diarrhea-from $22 \%$ (low-case scenario, $17 \%$; high-case scenario, $28 \%$ ) in studies published between 1986 and 1999 to 39\% (low-case scenario, $29 \%$; high-case scenario, $45 \%$ ) in studies published from 2000 to 2004.

This study's estimates for rotavirusassociated diarrhea for the 2004 Brazilian birth cohort's first 5 years of life compared reasonably well with those from other studies (49), whose calculations indicated 712249 visits to a healthcare facility (very close to this study's base-case scenario estimate of 655853 ) and 120513 hospitalizations (very close to this study's high-case scenario estimate of 116199 ) due to rotavirus-associated diarrhea. However, other studies' estimates of rotavirus-associated deaths (2 475) seems overestimated, considering there were 2913 deaths among children under 5 from all causes of diarrhea in 2003, according to SUS Mortality Information System records.

The risk of dying from rotavirusassociated diarrhea by age 5 estimated in this study (1 in 3777 ) is smaller than that estimated by Parashar et al. (1 in 1152 ) for the "upper-middle-income" category of country economies defined by the World Bank (8), which includes
Brazil. Parashar et al. (8) estimated the proportion of deaths among children under 5 attributable to diarrhea for this group of countries at $9 \%$, whereas the 2913 deaths attributed to diarrhea among children under 5 in Brazil in 2003 , as per national health database (DATASUS) mortality records, represent $4.3 \%$ of all deaths of children in that age group.

Since March 2006, the monovalent human attenuated rotavirus vaccine has been included in Brazil's National Immunization Program, recommended for administration to all children at 2 and 4 months of age. The main objective of this immunization program is to prevent hospitalizations and deaths from severe rotavirus-associated disease. This study's estimates of rotavirusassociated morbidity and mortality among Brazilian children $\leq 5$ years of age in the pre-vaccine era may serve as a baseline to monitor the impact of the rotavirus vaccine's introduction in routine childhood immunization in Brazil.

Acknowledgment. This study is part of a project evaluating the economic impact of introducing new vaccines into Brazil's National Immunization Program, supported by the Brazilian Ministry of Health. 


\section{REFERENCES}

1. Ahmad OB, Lopez AD, Inoue M. The decline in child mortality: a reappraisal. Bull World Health Organ. 2000;78(10):1175-91.

2. Fuchs SC, Victora CG, Fachel J. Modelo hierarquizado: uma proposta de modelagem aplicada à investigação de fatores de risco para diarréia grave. Rev Saúde Pública. 1996; 30(2):168-78.

3. Victora CG. Intervenções para reduzir a mortalidade infantil pré-escolar e materna no Brasil. Rev Bras Epidemiol. 2001;4(1):3-69.

4. Sastry N, Burgard S. The prevalence of diarrheal disease among Brazilian children: trends and differentials from 1986 to 1996. Soc Sci Med. 2005;60(5):923-35.

5. Kale PL, Fernandes C, Nobre FF. Padrão temporal das internações e óbitos por diarréia em crianças, 1995 a 1998, Rio de Janeiro. Rev Saúde Pública. 2004;38(1):30-7.

6. Kale PL, Andreozzi VL, Nobre FF. Time series analysis of deaths due to diarrhoea in children in Rio de Janeiro, Brazil, 1980-1998. J Health Popul Nutr. 2004;22(1):27-33.

7. Parashar UD, Gibson CI, Bresee JS, Glass RI. Rotavirus and severe childhood diarrhea. Emerg Infect Dis. 2006;12(2):304-6.

8. Parashar UD, Hummemman EG, Bresee JS, Miller MA, Glass RI. Global illness and deaths caused by rotavirus disease in children. Emerg Infect Dis. 2003;9(5):565-72.

9. World Health Organization. Rotavirus vaccines [Position Paper]. Wkly Epidemiol Rec. 2007 Aug 10;82(32):285-95.

10. Ruiz-Palácios GM, Pérez Schael I, Velásquez FR, Abate H, Breuer T, Clemens SC, et al. Safety and efficacy of an attenuated vaccine against severe rotavirus gastroenteritis. New Engl J Med. 2006;354(1):11-22.

11. Vesikari T, Matson DO, Dennehy P, Van Damme P, Santosharn M, Rodriguez Z, et al. Safety and efficacy of a pentavalent humanbovine (WC3) reassortant rotavirus vaccine. New Engl J Med. 2006;354(1):23-33.

12. Brasil, Secretaria de Estado da Saúde de São Paulo, Coordenadoria de Controle de Doenças, Centro de Vigilância Epidemiológica "Prof. Alexandre Vranjac," Divisão de Imunização e Divisão de Doenças de Transmissão Hídrica e Alimentar. Vacina contra rotavirus. Rev Saúde Pública. 2006;40(2):355-8.

13. Brasil, Ministério da Saúde, Doença Diarréica por Rotavírus. Vigilância epidemiológica e prevenção pela Vacina Oral de Rotavirus Humano-VORH [Informe Técnico]. 1 March 2006. Available from: http://portal.saude. gov.br/portal/arquivos/pdf/informe rotavirus_02_03_2006.pdf. Accessed 19 November 2006.

14. World Health Organization. Converting 2week diarrhoea prevalence to 2-week incidence and estimating annual incidence rate from 2-week incidence [Appendix]. Available from: http://whqlibdoc.who.int/hq/1994/ who_CDR_94_8_annexes_r_v.pdf. Accessed 15 November 2007.

15. Brasil, Ministério da Saúde, Departamento de Informática do Sistema Único de Saúde (DATASUS), Informações de Saude: Morbidade Hospitalar do SUS [Internet site]. Avail- able from: http://tabnet.datasus.gov.br/cgi/ tabcgi.exe?sih/cnv/mruf.def. Accessed 9 January 2006.

16. Brasil, Ministério da Saúde, Departamento de Informática do Sistema Único de Saúde (DATASUS), Informações de Saude: Mortalidade [Internet site]. Available from: http:// tabnet.datasus.gov.br/cgi/tabcgi.exe?sim/ cnv/obtuf.def. Accessed 9 January 2006.

17. Castello AA, Arvay ML, Glass RI, Gentsch J. Rotavirus strain surveillance in Latin America: a review of the last nine years. Pediatr Infect Dis J. 2004;23(suppl 10):S168-72.

18. Brasil, Instituto Brasileiro de Geografia e Estatística [Internet site]. Available from: http://www.ibge.gov.br. Accessed November 2005.

19. Lima AA, Moore SR, Barboza Jr MS, Soares AM, Schleupner MA, Newman RD, et al. Persistent diarrhea signals a critical period of increased diarrhea burdens and nutritional shortfalls: a prospective cohort study among children in Northeastern Brazil. J Infect Dis. 2000;181:1643-51.

20. Moore SR, Lima AA, Shorling JB, Barboza Jr MS, Soares AS, Guerrant RL. Changes over time in the epidemiology of diarrhea and malnutrition among children in an urban Brazilian shantytown, 1989 to 1996. Int J Infect Dis. 2000;4(4):179-86.

21. Moraes LR, Cancio JA, Cairncross S, Huttly S. Impact of drainage and sewerage on diarrhoea in poor urban areas in Salvador, Brazil. Trans R Soc Trop Med Hyg. 2003;97(2):153-8.

22. Strina A, Cairncross S, Prado MS, Teles CA, Barreto ML. Childhood diarrhoea symptoms, management and duration: observations from a longitudinal community study. Trans R Soc Trop Med Hyg. 2005;99(6): 407-16.

23. Barreto ML, Milroy CA, Strina A, Prado MS, Leite JP, Ramos EA, et al. Community-based monitoring of diarrhea in urban Brazilian children: incidence and associated pathogens. Trans R Soc Trop Med Hyg. 2006;100(3):234-42.

24. Vázquez ML, Mosquera M, Cuevas LE, González ES, Veras IC, Luz EO, et al. Incidência e fatores de risco de diarréia e infecções respiratórias agudas em comunidades urbanas de Pernambuco, Brasil. Cad. Saúde Pública (Rio J). 1999;15(1):163-71.

25. Escuder MM, da Silva NN, Pereira JC, Puccini RF, Herrman AA. Assessing morbidity in the paediatric community. Rev Saúde Pública. 1999;33(4):349-57.

26. Benício MH, Monteiro CA. Tendência secular da doença diarréica na infância na cidade de São Paulo (1985-1996). Rev Saúde Pública. 2000;34(6 supl):83-90.

27. Vieira GO, Silva LR, Vieira TO. Child feeding and diarrhea morbidity. J Pediatr (Rio J). 2003; 79(5):449-54.

28. Brasil, Instituto Brasileiro de Geografia e Estatística, Pesquisa Nacional por Amostra de Domicílios-PNAD 2003 [Internet site]. Acesso e utilização de serviços de saúde 2003. Available from: http://www.ibge.gov.br/home/ estatistica/populacao/trabalhoerendimento/ pnad2003/coeficiente_brasil.shtm. Accessed 3 January 2007.
29. Araújo IT, Fialho AM, de Assis RM, Rocha M, Galvão M, Cruz CM, et al. Rotavirus strain diversity in Rio de Janeiro, Brazil: characterization of VP4 and VP7 genotypes in hospitalized children. J Trop Pediatr. 2002;48(4):214-8.

30. Domingues AL, Da Silva Vaz MG, Moreno M, Câmara FP. Molecular epidemiology of group A rotavirus causing acute diarrhea in infants and young children hospitalised in Rio de Janeiro, Brazil, 1995-1996. Braz J Infect Dis. 2000;4(3):119-25.

31. Gusmão RH, Mascarenhas JD, Gabbay IB, Lins-Lainson Z, Ramos FL, Monteiro TA, et al Rotavirus subgroups, G serotypes, and electrophoretypes in cases of nosocomial infantile diarrhea in Belém, Brazil. J Trop Pediatr. 1999; 45(2):81-6.

32. Cardoso DD, Soares CM, Dias e Souza MB, de Azevedo MDS, Martins RM, Queiroz DA, et al. Epidemiological features of rotavirus infection in Goiânia, Goiás, Brazil, from 1986 to 2000. Mem Inst Oswaldo Cruz (Rio J). 2003; 98(1):25-9.

33. da Rosa e Silva ML, Carvalho IP, Gouvea V. 1998-1999 rotavirus seasons in Juiz de Fora, Minas Gerais, Brazil: detection of an unusual G3P[4] epidemic strain. J Clin Microbiol. 2002; 40(8):2837-42.

34. Santos N, Volotão EM, Soares CC, Campos GS, Sardi SI, Hoshino Y. Predominance of rotavirus genotype G9 during the 1999, 2000 and 2002 seasons among hospitalized children in the city of Salvador, Bahia, Brazil: implications for future vaccine strategies. J Clin Microbiol. 2005; 43(8):4064-9.

35. Luz CR, Mascarenhas JD, Gabbay YB, Motta AR, Lima TV, Soares LS, et al. Rotavirus serotypes and electropherotypes identified among hospitalised children in São Luis, Maranhão, Brazil. Rev Inst Med Trop São Paulo. 2005;47(5):287-93

36. Carmona RC, Timenetsky Mdo C, da Silva FF Granato CF. Characterization of rotavirus strains from hospitalized and outpatient children with acute diarrhoea in São Paulo, Brazil. J Med Virol. 2004;74(1):166-72.

37. Volotão EM, Soares CC, Maranhão AG, Rocha LN, Hoshino Y, Santos N. Rotavirus surveillance in the city of Rio de Janeiro-Brazil during 2000-2004: detection of unusual strains with G8P[4] or G10P[9] specificities. J Med Virol. 2006;78:263-72.

38. Fernandes JV, Fonseca SM, Azevedo JC, Maranhão HS, Fonseca MH, Dantas MT, et al Rotavirus detection in feces of children with acute diarrhea. J Pediatr (Rio J). 2000;76(4): 300-4.

39. Soares CC, Volotão EM, Albuquerque MC, da Silva FM, de Carvalho TR, Nozawa CM, et al. Prevalence of enteric adenoviruses among children with diarrhea in four Brazilian cities. J Clin Virol. 2002;23(3):171-7.

40. Bittencourt JA, Arbo E, Malysz AS, Oravec R, Dias C. Seasonal and age distribution of rotavirus infection in Porto Alegre, Brazil. Braz J Infect Dis. 2000;4(6):279-83.

41. Santos N, Volotão EM, Soares CC, Albuquerque MC, da Silva FM, de Carvalho TR, et al. Rotavirus strains bearing genotype G9 
or $\mathrm{P}[9]$ recovered from Brazilian children with diarrhea from 1997 to 1999. J Clin Microbiol. 2001;39(3):1157-60.

42. Kane EM, Turcios RM, Arvay ML, Garcia S, Bresee JS, Glass RI. The epidemiology of rotavirus diarrhea in Latin America. Anticipating rotavirus vaccine. Rev Panam Salud Pública. 2004;16(6):371-7.

43. Gómez JA, Nates S, De Castagnaro NR, Espul C, Borsa A, Glass RI. Anticipating rotavirus vaccines: review of epidemiologic studies of rotavirus diarrhea in Argentina. Rev Panam Salud Pública. 1998;3(2):69-78.

44. O'Ryan M, Perez-Schael I, Mamani N, Pena A, Salinas B, Gonzalez G, et al. Rotavirus-associated medical visits and hospitalizations in South America: a prospective study at three large sentinel hospitals. Pediatr Infect Dis J. 2001;20(7):685-93.
45. Salinas B, Gonzalez G, Gonzalez R, Escalona M, Materan M, Schael IP. Epidemiologic and clinical characteristics of rotavirus disease during five years of surveillance in Venezuela. Pediatr Infect Dis J. 2004;23(suppl 10): S161-7.

46. Guardado JA, Clará WA, Turcios RM, Fuentes RA, Valencia D, Sandoval, R, et al. Rotavirus in El Salvador: an outbreak, surveillance and estimates of disease burden, 2000-2002. Pediatr Infect Dis J. 2004;23(suppl 10):S156-60.

47. Ehrenkranz P, Lanata CF, Penny ME, SalazarLindo E, Glass RI. Rotavirus diarrhea disease burden in Peru: the need for a rotavirus vaccine and its potential cost savings. Rev Panam Salud Pública. 2001;10(4):240-8.

48. Pan American Health Organization, Family and Community Health Area, Immunization Unit. Regional Meeting on the Implementa- tion of Rotavirus Epidemiological Surveillance: generating information for decisionmaking. [Final Report]. Washington, D.C.: PAHO; 2003. (PAHO/IM/2003-00005).

49. Rheigans RD, Constenla D, Antil L, Innis BL, Breuer T. Economic and health burden of rotavirus gastroenteritis for the 2003 birth cohort in eight Latin American and Caribbean countries. Rev Panam Salud Pública. 2007; 21(4):192-204.

Manuscript received on 12 June 2007. Revised version accepted for publication on 20 November 2007.

RESUMEN Objetivos. Analizar la epidemiología del rotavirus y estimar la morbilidad y la mortalidad asociadas con las infecciones por rotavirus en niños $\leq 5$ años de edad en Brasil en 2004, antes de incluir la vacuna contra el rotavirus en el Programa Nacional de

Morbilidad y mortalidad por rotavirus en niños en Brasil

Palabras clave
Inmunizaciones (PNI).

Métodos. Para estimar la morbilidad por rotavirus se revisaron los estudios publicados (1999-2006) que abordaban la incidencia de diarrea aguda en niños $\leq 5$ años de edad y la frecuencia de las infecciones por rotavirus en niños con diarrea en Brasil. Los casos de diarrea se dividieron en tres categorías de gravedad según el nivel de atención que requirieron: casos leves que solo requirieron atención domiciliaria, casos moderados que requirieron la visita a un servicio ambulatorio de salud y casos graves que requirieron hospitalización. Para estimar la mortalidad por rotavirus se utilizó el número de muertes registradas por diarrea en niños de $\leq 5$ años, según el Sistema de Información sobre Mortalidad (SIM) del Sistema Único de Salud (SUS) de Brasil, y se calculó la proporción de muertes causadas por este virus.

Resultados. Se estimó que las infecciones por rotavirus causan anualmente 3525053 casos de diarrea, 655853 visitas a servicios ambulatorios de salud, 92453 hospitalizaciones y 850 muertes en niños $\leq 5$ años de edad en Brasil.

Conclusiones. Las infecciones por rotavirus constituyen una importante causa de morbilidad y mortalidad en Brasil.

Infecciones por rotavirus, morbilidad, mortalidad, Brasil. 